\title{
INFLUENCE OF PU-ERH TEA EXTRACT ON PHYSICOCHEMICAL AND FUNCTIONAL PROPERTIES OF GERMINATED BROWN RICE
}

\author{
Jeong-Ho Kim ${ }^{1}$, Yong-Han Yoon ${ }^{1}$, Il-Doo Kim² ${ }^{2}$, Sanjeev Kumar Dhungana ${ }^{3}$, Dong-Hyun Shin ${ }^{4 凶}$ \\ ${ }^{1}$ Department of Green Technology Convergence, Konkuk University, Chungju 27478, Korea \\ 2 International Institute of Research \& Development, Kyungpook National University, Daegu 41566, Korea \\ ${ }^{3}$ Department of Southern Area Crop Science, National Institute of Crop Science, Rural Development \\ Administration, Miryang 50424, Korea \\ ${ }^{4}$ School of Applied Biosciences, Kyungpook National University, Daegu 41566, Korea \\ 凶dhshin@knu.ac.kr \\ https://doi.org/10.34302/crpjfst/2021.13.3.15
}

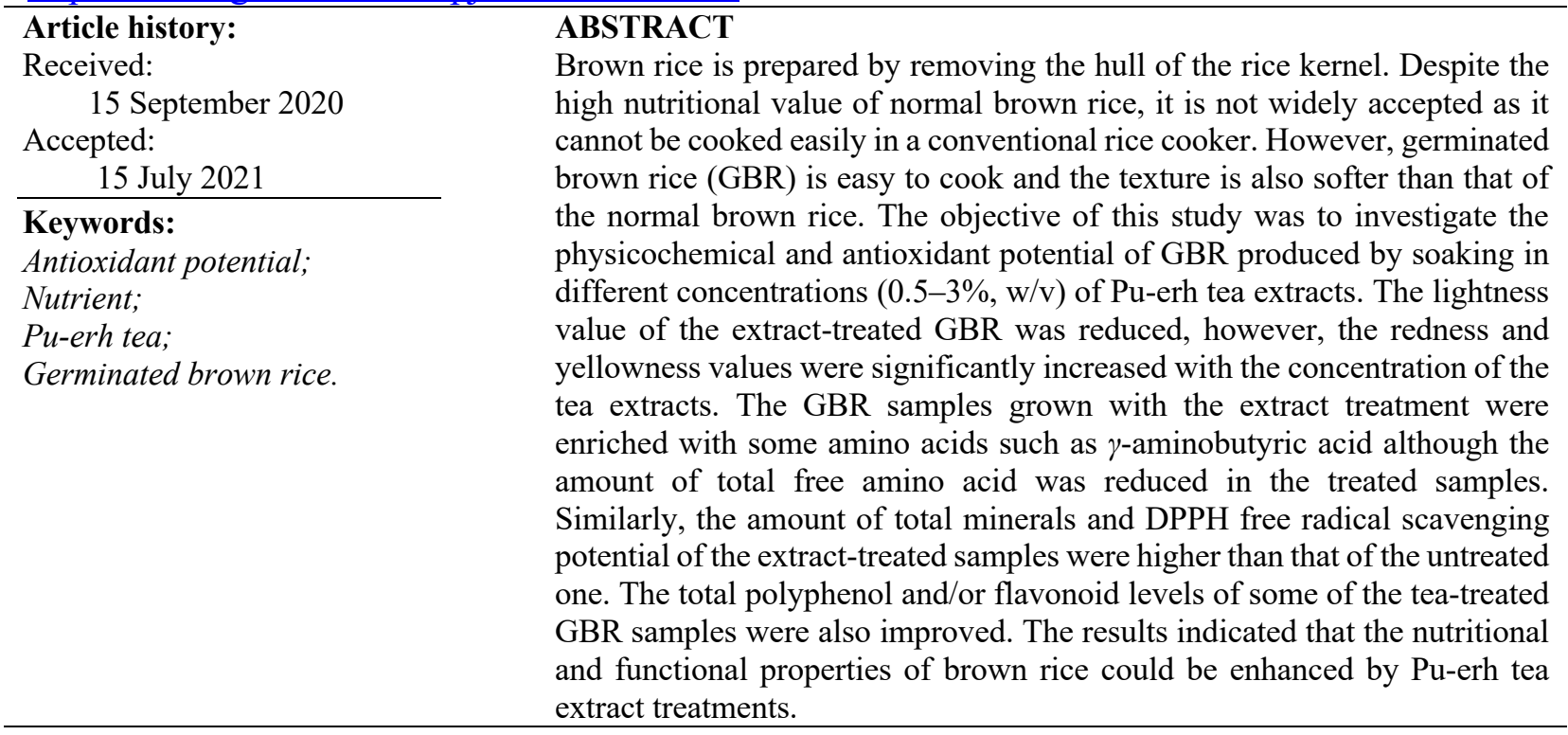

\section{Introduction}

Rice supplies daily calories for about half of the world's population. Rice literally means white rice, also known as polished rice. Brown rice is prepared by removing only the outermost layer, the hull, of the rice kernel, and is the least damaging to its nutritional value. However, white rice is produced by further milling and removing the bran and most of the germ layer from brown rice. Brown rice is healthier than polished rice (Dinesh Babu et al., 2009). Brown rice has high dietary fiber, rich in vitamin $\mathrm{B}$ complex and minerals, and high in fat. Also, it has been reported that brown rice contains high phytic acid, antioxidant, and anti-cancer; it decreases serum cholesterol; and it is considered a low glycemic index food.

Although normal brown rice has high nutritional value, its popularity is low because it cannot be cooked in a conventional rice cooker, however, germinated brown rice (GBR) is easily cooked and the texture is softer than that of brown rice (Komatsuzaki et al., 2007; Patil and Khan, 2011). Therefore, GBR could become a popular healthy food. Several studies on GBR indicate that during the process of germination, nutrients in the brown rice change drastically. Not only the contents of existing nutrients are modified but new components are also released due to germination (Spanier et al., 2001). GBR 
is more beneficial than normal brown rice and white rice, particularly in the prevention of some diet-related diseases, including obesity, type 2 diabetes, and colorectal cancers (Imam et al., 2014). An intake of GBR instead of white rice is good for the control of postprandial blood glucose concentration without increasing insulin secretion in subjects with hyperglycemia (Ito et al., 2005). Intake of GBR is suggested to protect cell proliferation and apoptosis as well as to prevent heart failure owing to myocardial ischemia (Petchdee et al., 2020).

The nutrients like $\gamma$-aminobutyric acid (GABA), lysine, vitamin E, dietary fiber, niacin, magnesium, vitamin $\mathrm{B} 1$, and vitamin $\mathrm{B} 6$ are significantly increased in GBR (Spanier et al., 2001). They found that regular intake of GBR is beneficial for preventing headaches, relieving constipation, preventing colon cancer, regulating blood sugar level and preventing heart disease. Intake of GABA suppresses blood pressure and improves sleeplessness and autonomic disorder observed during the menopausal or presenile period (Okada et al., 2000).

Reports show that different pretreatments and/or cultivation techniques have been employed to enhance the quality of GBR. Apoptotic pathway is found to be activated in the Lactobacillus acidophilus-fermented GBR that may prevent preneoplastic lesions of the colon (Li et al., 2019). Gamma oryzanols contents are increased in the cold plasma-treated GBR compared to the untreated GBR (Yodpitak et al., 2019). Gamma oryzanols is reported to increase the muscle strength (Eslami et al., 2014). The GABA content is substantially increased following the cellulase solution treatment to GBR (Zhang et al., 2019). Germination of brown rice in red onion solution increases the antioxidant capacity and GABA content as well as makes the rice slightly softer and stickier than that germinated in water (Nakamura et al., 2020).

$\mathrm{Pu}$-erh tea is receiving increased attention due to its health benefits for a variety of hypolipidemic, antiobesity, antimutagenic, antioxidative, antitumor, free radical scavenging, and toxicity suppressing activities (Lee and Foo, 2013). Extracts obtained from plant sources have been found to increase the quality of soybean sprouts (Chaikina et al., 2009; Kim et al., 2017). So far, no reports on the effect of phytochemical-rich Pu-erh tea on GBR have been published. Considering the health benefits of Pu-erh tea and GBR, this study was conducted to investigate the effect of Pu-erh tea on the nutritional and functional values of GBR. This study will provide an insight into the effects of functional food material, such as Pu-erh tea on the quality of GBR.

\section{Materials and methods}

\subsection{Chemicals and materials}

Folin-Ciocalteu phenol reagent, quercetin, gallic acid, and 1,1-diphenly-2-picrylhydrazyl (DPPH) were purchased from Sigma-Aldrich (Sigma-Aldrich Corp, St. Louis, MO, USA) and amino acid standards were obtained from Wako (Wako Pure Chemical Industries, Ltd., Osaka, Japan). All the chemicals used in this study were of analytical grade.

Brown rice (Oryza sativa L.) obtained from a Korean rice cultivar Ilpum Byeo was used in this study. A typical wild Pu-erh tea, produced in the Yunnan province of China, was considered to prepare tea extracts.

\subsection{Production of germinated brown rice and sample powder}

One kilogram of brown rice was washed with tap water and soaked in tap water alone or three different concentrations $(0.5,1.5$, and $3 \%$; $\mathrm{w} / \mathrm{v}$ ) of Pu-erh tea extracts prepared in tap water for $1 \mathrm{~h}$. The sample soaked in tap water alone, $0.5,1.5$, and $3 \% \mathrm{Pu}$-erh tea extracts was named GBR-0, GBR-0.5, GBR-1.5, and GBR-3, respectively. After soaking for $1 \mathrm{~h}$, the brown rice samples were put into an incubator $\left(35^{\circ} \mathrm{C}\right)$ for $36 \mathrm{~h}$ to allow germination. The rice samples were kept in net bags and moistened every $1 \mathrm{~h}$ by brief dipping in the respective solutions used for the pre-soaking.

The freshly harvested GBR samples were kept at $-70{ }^{\circ} \mathrm{C}$ for $24 \mathrm{~h}$ before freeze-drying. The freeze-dried samples were ground into powder 
using a commercial grinder (HIL-G-501, Hanil Co., Seoul, Korea) and filtered through a 100mesh sieve.

\subsection{Color measurement}

The color values of powdered samples were determined following the Hunter's color measurement system as described earlier (Kim et al., 2014). The 'L' (lightness), 'a' (redness), and ' $b$ ' (yellowness) values were measured using a Chroma Meter (CR-300, Minolta Corp, Tokyo, Japan). A calibration plate (Minolta Corp.; YCIE $=94.5, \mathrm{XCIE}=0.3160, \mathrm{YCIE}=$ 0.330 ) and a standard plate (Hunter Associates Laboratory Inc., Reston, VA, USA; 'L'=97.51, $' \mathrm{a}=-0.18, ' \mathrm{~b}$ '= 1.67) were considered for standardizing the instrument with D65 illuminant.

\subsection{Determination of free amino acid}

The free amino acids were analyzed following the method described by Je et al. (2005). The powdered sample (1.5 g) was homogenized (12000 rpm, $2 \mathrm{~min}$ ) with $10 \mathrm{~mL}$ of ice-cold $6 \%(\mathrm{v} / \mathrm{v})$ perchloric acid in an ice bath using an ACE homogenizer (Nissei AM-7, Nihonseikei Kaisha Ltd, Tokyo, Japan) and then kept in ice for $30 \mathrm{~min}$ before centrifugation (5000 rpm, $15 \mathrm{~min}$ ). The supernatant was filtered using a filter paper (Whatman No. 41). The $\mathrm{pH}$ of the filtrate was adjusted to 7 using a $\mathrm{KOH}$ solution $(33 \%$, w/v), and centrifuged (5000 rpm, $10 \mathrm{~min}$ ). After centrifugation, the precipitate of potassium perchlorate was removed and the $\mathrm{pH}$ of the mixture was adjusted to 2.2 using $10 \mathrm{M} \mathrm{HCl}$ and then the final volume of the mixture was made $50 \mathrm{~mL}$ with distilled water. Two milliliters of the mixture were mixed with $1 \mathrm{~mL}$ lithium citrate buffer $(\mathrm{pH} 2.2)$ and the free amino acid profile was analyzed using an automatic amino acid analyzer (Biochrom-20, Pharmacia Biotech Co., Uppsala, Sweden).

\subsection{Determination of mineral content}

The amount of mineral elements was measured using an inductively coupled plasma atomic emission spectrometer (ICP AES: Varian Vista, Victoria, Australia) as described earlier (Skujins, 1998). Five hundred milligrams of powdered sample was digested in a mixture of $65 \% \mathrm{HNO}_{3}(15.0 \mathrm{~mL})$ and $35 \% \mathrm{H}_{2} \mathrm{O}_{2}(2 \mathrm{~mL})$. The mixture was diluted with an equal volume of distilled water. The amount of different mineral elements was measured after calibrating the ICP AES with known standards.

\subsection{Preparation of sample extracts for antioxidant assays}

One gram of the powdered sample was extracted in $10 \mathrm{~mL}$ of absolute methanol using a shaking incubator $\left(250 \mathrm{rpm}, 25^{\circ} \mathrm{C}\right)$ for $2 \mathrm{~h}$ and the mixture was centrifuged $(1660 \times g, 15 \mathrm{~min})$. The supernatant was filtered through a syringe filter $(0.2 \mu \mathrm{m})$ and the filtrate extract was used for further analyses.

\subsection{Determination of DPPH radical scavenging activity}

The DPPH free radical scavenging potential of GBR samples was measured following the methods described earlier (Blois, 1958; Dhungana et al., 2015). One hundred microliters of sample extract and freshly prepared $0.05 \%$ $(\mathrm{w} / \mathrm{v})$ methanolic solution of DPPH were mixed in wells of the 96-well microplate and incubated at room temperature for $30 \mathrm{~min}$ under dark condition. After $30 \mathrm{~min}$ of incubation, the absorbance values of the reaction mixtures were measured at $517 \mathrm{~nm}$ using a spectrophotometer (Multiskan GO, Thermo Fisher Scientific Oy, Vantaa, Finland). The free radical scavenging potential was calculated as follows.

Scavenging potential (\%)

$$
=\left[1-\left(\mathrm{S}-\mathrm{S}_{\mathrm{o}}\right) /\left(\mathrm{C}-\mathrm{C}_{\mathrm{o}}\right)\right] \times 100
$$

where $\mathrm{S}, \mathrm{S}_{\mathrm{o}}, \mathrm{C}$, and $\mathrm{C}_{\mathrm{o}}$ are the absorbance values of the sample and DPPH, sample and methanol, methanol and DPPH, and methanol, respectively.

\subsection{Determination of total polyphenol content}

The total polyphenol content (TPC) of GBR samples was determined according to the FolinCiocalteau method (Singleton et al., 1999) as described by Dhungana et al. (2016). Fifty microliters of the sample extracts and $1 \mathrm{~mL}$ of $2 \%(\mathrm{w} / \mathrm{v})$ aqueous $\mathrm{Na}_{2} \mathrm{CO}_{3}$ were mixed in 
microtubes and allowed to react at room temperature for $3 \mathrm{~min}$. After $3 \mathrm{~min}$, fifty microliters of $1 \mathrm{~N}$ Folin-Ciocalteau reagent was mixed into the mixture and incubated at room temperature for $30 \mathrm{~min}$ under dark condition. The absorbance value of the reaction mixtures was measured at $750 \mathrm{~nm}$ using a microplate spectrophotometer (Multiskan GO; Thermo Fisher Scientific). The total polyphenol content of the samples was calculated using the calibration curve drawn using gallic acid (GA) as standard.

\subsection{Flavonoid content analysis}

The flavonoid content of GBR samples was measured following the procedure described earlier (Zhishen et al., 1999; Dhungana et al., 2016). One hundred microliters of the sample extracts, $500 \mu \mathrm{L}$ absolute methanol, $50 \mu \mathrm{L} \mathrm{10 \%}$ $\mathrm{AlCl}_{3}, 50 \mu \mathrm{L} 1 \mathrm{M} \mathrm{HCl}$, and $300 \mu \mathrm{L}$ distilled water were mixed in microtubes and incubated as in the TPC determination method. After the 30 min incubation, absorbance values of the reaction mixtures were measured at $510 \mathrm{~nm}$ using a microplate spectrophotometer (Multiskan GO; Thermo Fischer Scientific). The flavonoid content of the samples was determined using the calibration curve plotted using quercetin as a standard.

\subsection{Statistical analysis}

Statistical analysis was performed through the analysis of variance using SAS 9.4 (SAS Institute, Cary, NC, USA). The significant differences between samples were determined using the Tukey test $(\mathrm{p}<0.05)$. The average values of three replicates are reported unless otherwise mentioned.

\section{Results and discussions}

\subsection{Color value of germinated brown rice}

The Hunter's color values of GBR were significantly affected by $\mathrm{Pu}$-erh tea extract treatment (Table 1). The lightness value of GBR was the highest in GBR-0 (82.7) and was significantly reduced with the concentration of tea extracts (73.96-78.88). On the contrary, the redness and yellowness values were the highest for GBR-0 (0.82 and 9.14) and significantly increased in the extract-treated samples (1.84-2.77 and 9.47-9.77) with the concentration of the tea extracts, respectively.

Table 1. Hunter's color values of germinated brown rice (GBR) produced after soaking in different concentration of $\mathrm{Pu}$-erh tea extracts

\begin{tabular}{|l|c|c|c|}
\hline \multirow{2}{*}{ Sample $^{1)}$} & \multicolumn{3}{|c|}{ Color value $^{2)}$} \\
\cline { 2 - 4 } & L (lightness) & a (redness) & b (yellowness) \\
\hline GBR-0 & $82.7 \pm 1.67 \mathrm{a}^{3)}$ & $0.82 \pm 0.16 \mathrm{~d}$ & $9.14 \pm 0.54 \mathrm{~d}$ \\
\hline GBR-0.5 & $78.88 \pm 0.39 \mathrm{~b}$ & $1.84 \pm 0.09 \mathrm{c}$ & $9.470 \pm 0.10 \mathrm{c}$ \\
\hline GBR-1.5 & $75.06 \pm 0.43 \mathrm{c}$ & $2.50 \pm 0.03 \mathrm{~b}$ & $9.51 \pm 0.07 \mathrm{~b}$ \\
\hline GBR-3 & $73.96 \pm 0.28 \mathrm{~d}$ & $2.77 \pm 0.03 \mathrm{a}$ & $9.77 \pm 0.07 \mathrm{a}$ \\
\hline
\end{tabular}

1) GBR-0: GBR produced after soaking the rice in tap water for $1 \mathrm{~h}$; GBR-0.5: GBR produced after soaking the rice in $0.5 \%$ (w/v) Pu-erh tea extract for $1 \mathrm{~h}$; GBR-1.5: GBR produced after soaking the rice in $1.5 \%(\mathrm{w} / \mathrm{v})$ Pu-erh tea extract for $1 \mathrm{~h}$; and GBR-3: GBR produced after soaking the rice in 3\% (w/v) Puerh tea extract for $1 \mathrm{~h} .{ }^{2)} \mathrm{L}$ : lightness (100, white; 0 , black); a: redness (-, green; +, red); b: yellowness (-, blue; +, yellow). ${ }^{3)}$ Values are presented as mean \pm standard deviation of three replicates. Values followed by different letters ( $a, b, c$, and d) in the same column indicate significant difference $(p<0.05$, ANOVA, Tukey test).

The effects of Pu-erh tea extracts on the physicochemical characteristics and antioxidant potentials of GBR were investigated in the present study. Visible traits such as the color of a food product are determining factors that affect the willingness of consumers to buy the product (Udomkun et al., 2018). The reasons for the variation in the color value of the GBR due to the tea extract treatments were not well understood in the present study.

\subsection{Free amino acid content}

The effect of tea extract treatments on GBR was less significant across samples when considered the free amino acid content (Table 2). A total of 25 (8 essential, 8 non-essential, and 9 other) amino acids were detected, whereas the amounts of 11 amino acids were non-detectable. The amounts of the essential, non-essential, and total amino acids were higher in the tea extractuntreated GBR than in the treated samples. However, the amount of some amino acids such as GABA was significantly higher in GBR-0.5 $(0.59 \mathrm{mg} / \mathrm{g})$ and GBR-1.5 $(0.59 \mathrm{mg} / \mathrm{g})$ than in GBR-0 (0.52 mg/g) and GBR-3 $(0.51 \mathrm{mg} / \mathrm{g})$. 
Calcium plays a role in the activation of diamine oxidase activity that subsequently influences GABA synthesis (Wang et al., 2016). High calcium content in Pu-erh tea might have increased the GABA content in two of the tea extract-treated GBR samples. However, the reason for reduced GABA content in GBR-3 could not be justified. Amino acids such as GABA and glycine are associated with learning and memory enhancement; stroke and neurodegenerative disease control; anxiety, sedation, and anticonvulsant relief; and muscle relaxation functions (Mody et al., 1994; Oh and Oh, 2004). The GABA-rich foods are beneficial for regulating blood cholesterol and pressure, decreasing insomnia and depression, and relieving pain (Dhakal et al., 2012) inhibiting sleeplessness and autonomic disorder observed during the menopausal or presenile period (Okada et al., 2000). GABA is also found as advantageous to control diabetes (Reeds, 2000).

Table 2. Free amino acid composition (mg/g of dry weight) of germinated brown rice (GBR) produced after soaking in different concentration of Pu-erh tea extracts

\begin{tabular}{|c|c|c|c|c|}
\hline \multirow{2}{*}{ Amino acid } & \multicolumn{4}{|c|}{ Sample $^{1)}$} \\
\hline & GBR-0 & GBR-0.5 & GBR-1.5 & GBR-3 \\
\hline \multicolumn{5}{|l|}{ Essential amino acid } \\
\hline L-Threonine & $0.04 \pm 0.01 \mathrm{a}^{2)}$ & $0.04 \pm 0.01 \mathrm{a}$ & $0.04 \pm 0.01 \mathrm{a}$ & $0.03 \pm 0.01 \mathrm{a}$ \\
\hline L-Valine & $0.11 \pm 0.01 \mathrm{a}$ & $0.09 \pm 0.02 \mathrm{ab}$ & $0.09 \pm 0.01 \mathrm{ab}$ & $0.07 \pm 0.01 \mathrm{~b}$ \\
\hline L-Methionine & $0.03 \pm 0.01 \mathrm{a}$ & $0.01 \pm 0.01 \mathrm{a}$ & $0.02 \pm 0.01 \mathrm{a}$ & $0.02 \pm 0.01 \mathrm{a}$ \\
\hline L-Isoleucine & $0.06 \pm 0.01 \mathrm{a}$ & $0.05 \pm 0.01 \mathrm{a}$ & $0.05 \pm 0.01 \mathrm{a}$ & $0.04 \pm 0.01 \mathrm{a}$ \\
\hline L-Leucine & $0.08 \pm 0.01 \mathrm{a}$ & $0.07 \pm 0.01 \mathrm{ab}$ & $0.06 \pm 0.02 \mathrm{ab}$ & $0.05 \pm 0.01 \mathrm{~b}$ \\
\hline L-Phenylalanine & $0.08 \pm 0.01 \mathrm{a}$ & $0.07 \pm 0.02 \mathrm{ab}$ & $0.06 \pm 0.01 \mathrm{ab}$ & $0.05 \pm 0.01 b$ \\
\hline L-Lysine & $0.07 \pm 0.01 \mathrm{a}$ & $0.06 \pm 0.02 \mathrm{a}$ & $0.06 \pm 0.01 \mathrm{a}$ & $0.05 \pm 0.01 \mathrm{a}$ \\
\hline L-Histidine & $0.09 \pm 0.02 \mathrm{a}$ & $0.07 \pm 0.01 \mathrm{a}$ & $0.06 \pm 0.01 \mathrm{a}$ & $0.06 \pm 0.01 \mathrm{a}$ \\
\hline Sub-total & 0.56 & 0.46 & 0.44 & 0.37 \\
\hline \multicolumn{5}{|l|}{ Non-essential amino acid } \\
\hline L-Asparitic acid & $0.04 \pm 0.01 \mathrm{a}$ & $0.03 \pm 0.01 \mathrm{a}$ & $0.04 \pm 0.01 \mathrm{a}$ & $0.04 \pm 0.02 \mathrm{a}$ \\
\hline L-Serine & $0.09 \pm 0.01 \mathrm{a}$ & $0.08 \pm 0.02 \mathrm{a}$ & $0.10 \pm 0.01 \mathrm{a}$ & $0.09 \pm 0.01 \mathrm{a}$ \\
\hline L-Glutamic acid & $0.31 \pm 0.03 \mathrm{ab}$ & $0.29 \pm 0.02 b$ & $0.35 \pm 0.01 \mathrm{a}$ & $0.32 \pm 0.02 \mathrm{ab}$ \\
\hline Glycine & $0.02 \pm 0.01 \mathrm{a}$ & $0.02 \pm 0.01 \mathrm{a}$ & $0.02 \pm 0.01 \mathrm{a}$ & $0.02 \pm 0.01 \mathrm{a}$ \\
\hline L-Alanine & $0.15 \pm 0.02 \mathrm{a}$ & $0.14 \pm 0.01 \mathrm{a}$ & $0.15 \pm 0.01 \mathrm{a}$ & $0.14 \pm 0.01 \mathrm{a}$ \\
\hline L-Tyrosine & $0.10 \pm 0.01 \mathrm{a}$ & $0.07 \pm 0.02 b$ & $0.06 \pm 0.01 \mathrm{~b}$ & $0.05 \pm 0.01 \mathrm{~b}$ \\
\hline L-Arginine & $0.17 \pm 0.01 \mathrm{a}$ & $0.12 \pm 0.01 \mathrm{~b}$ & $0.11 \pm 0.02 \mathrm{bc}$ & $0.09 \pm 0.01 \mathrm{c}$ \\
\hline Proline & $0.05 \pm 0.01 \mathrm{a}$ & $0.05 \pm 0.01 \mathrm{a}$ & $0.04 \pm 0.01 \mathrm{a}$ & $0.04 \pm 0.01 \mathrm{a}$ \\
\hline Sub-total & 0.93 & 0.80 & 0.87 & 0.79 \\
\hline \multicolumn{5}{|l|}{ Other amino acid } \\
\hline O-Phospho-L-serine & $\mathrm{ND}^{3)}$ & ND & ND & ND \\
\hline Taurine & ND & ND & ND & ND \\
\hline O-Phospho ethanol amine & $0.02 \pm 0.01 \mathrm{a}$ & $0.02 \pm 0.01 \mathrm{a}$ & $0.02 \pm 0.01 \mathrm{a}$ & $0.02 \pm 0.01 \mathrm{a}$ \\
\hline L-Sarcosine & ND & ND & ND & ND \\
\hline L- $\alpha$-Amino asipic acid & $0.01 \pm 0.01 \mathrm{a}$ & $0.01 \pm 0.01 \mathrm{a}$ & $0.01 \pm 0.01 \mathrm{a}$ & $0.01 \pm 0.01 \mathrm{a}$ \\
\hline L-Citrulline & ND & ND & ND & ND \\
\hline L- $\alpha$-Amino-n-butyric acid & $0.01 \pm 0.01 \mathrm{a}$ & $0.01 \pm 0.01 \mathrm{a}$ & $0.01 \pm 0.01 \mathrm{a}$ & $0.01 \pm 0.01 \mathrm{a}$ \\
\hline L-Cystine & ND & ND & ND & ND \\
\hline
\end{tabular}




\begin{tabular}{|l|c|c|c|c|}
\hline Cystathionine & ND & ND & ND & ND \\
\hline$\beta$-Alanine & $0.03 \pm 0.01 \mathrm{a}$ & $0.03 \pm 0.01 \mathrm{a}$ & $0.03 \pm 0.01 \mathrm{a}$ & $0.03 \pm 0.01 \mathrm{a}$ \\
\hline D,L- $\beta$-Amino isobutyric acid & $0.02 \pm 0.01 \mathrm{a}$ & $0.02 \pm 0.01 \mathrm{a}$ & $0.04 \pm 0.01 \mathrm{a}$ & $0.02 \pm 0.01 \mathrm{a}$ \\
\hline$\gamma$-Amino-n-butyric acid & $0.52 \pm 0.01 \mathrm{~b}$ & $0.59 \pm 0.02 \mathrm{a}$ & $0.59 \pm 0.01 \mathrm{a}$ & $0.51 \pm 0.02 \mathrm{~b}$ \\
\hline Ethanolamin & $0.01 \pm 0.01 \mathrm{a}$ & $0.02 \pm 0.01 \mathrm{a}$ & $0.03 \pm 0.01 \mathrm{a}$ & $0.01 \pm 0.01 \mathrm{a}$ \\
\hline Hydroxylysine & ND & ND & ND & ND \\
\hline L-Ornithine & $0.01 \pm 0.01 \mathrm{a}$ & $0.01 \pm 0.01 \mathrm{a}$ & $0.01 \pm 0.01 \mathrm{a}$ & $0.01 \pm 0.01 \mathrm{a}$ \\
\hline 1-Methyl-L-histidine & $0.03 \pm 0.01 \mathrm{a}$ & $0.02 \pm 0.01 \mathrm{a}$ & $0.02 \pm 0.01 \mathrm{a}$ & $0.02 \pm 0.01 \mathrm{a}$ \\
\hline 3-Methyl-L-histidine & ND & ND & ND & ND \\
\hline L-Anserine & ND & ND & ND & ND \\
\hline L-Carnosine & ND & ND & ND & ND \\
\hline Hydroxy proline & ND & ND & ND & ND \\
\hline Sub-total & 0.66 & 0.73 & 0.76 & 0.64 \\
\hline Total free amino acid & 2.15 & 1.99 & 2.07 & 1.80 \\
\hline
\end{tabular}

1) Samples are defined in Table $1 .{ }^{2)}$ Values are expressed as mean \pm standard deviation of two replicates. Values followed by different letters ( $a, b, c$, and $d)$ in the same row are significantly different $\left(p<0.05\right.$, ANOVA, Tukey test). ${ }^{3)}$ Non-detected.

\subsection{Mineral content}

Although the amount of total free amino acids was lower in the Pu-erh tea extracttreated GBR samples, the treatment significantly increased many mineral elements along with the total mineral content (Table 3). Out of the eight minerals measured, five were higher in one of the tea extract-treated GBR than in the untreated sample. The amounts of two minerals $\mathrm{Ca}$ and $\mathrm{Cu}$ were significantly higher in the tea extract-untreated GBR (35.35 and 31.57 $\mathrm{mg} / \mathrm{kg}$ ) than in the extract-treated samples $(21.75-26.31$ and $12.54-30.39 \mathrm{mg} / \mathrm{kg})$, respectively. K (1417.57-1759.23 $\mathrm{mg} / \mathrm{kg})$ was the most abundant mineral in the GBR samples. The amount of total mineral content in the tea extract-treated GBR was substantially higher than that in the untreated sample.
Table 3. Mineral contents (mg/kg of dry weight) of germinated brown rice (GBR)

produced after soaking in different concentration of $\mathrm{Pu}$-erh tea extracts

\begin{tabular}{|c|c|c|c|c|}
\hline \multirow{2}{*}{$\begin{array}{l}\text { Elem } \\
\text { ent }\end{array}$} & \multicolumn{4}{|c|}{ Sample $^{1)}$} \\
\hline & GBR-0 & GBR-0.5 & GBR-1.5 & GBR-3 \\
\hline $\mathrm{Ca}$ & $\begin{array}{c}35.64 \pm 3.8 \\
7 \mathrm{a}^{2)}\end{array}$ & $\begin{array}{c}26.31 \pm 2.0 \\
0 \mathrm{~b}\end{array}$ & $\begin{array}{c}25.69 \pm 0 \\
86 \mathrm{~b}\end{array}$ & $\begin{array}{c}21.75 \pm 1.7 \\
0 \mathrm{c}\end{array}$ \\
\hline $\mathrm{Cu}$ & $\begin{array}{c}31.57 \pm 0.2 \\
6 \mathrm{a} \\
\end{array}$ & $\begin{array}{c}21.49 \pm 0.3 \\
9 \mathrm{c} \\
\end{array}$ & $\begin{array}{c}30.39 \pm 0 . \\
26 \mathrm{~b}\end{array}$ & $\begin{array}{c}12.54 \pm 0.0 \\
9 \mathrm{~d}\end{array}$ \\
\hline $\mathrm{Fe}$ & $\begin{array}{c}35.54 \pm 0.1 \\
6 \mathrm{~b}\end{array}$ & $\begin{array}{c}34.97 \pm 0.5 \\
2 b\end{array}$ & $\begin{array}{c}43.99 \pm 1 \\
48 \mathrm{a}\end{array}$ & $\begin{array}{c}22.62 \pm 0.1 \\
6 \mathrm{c}\end{array}$ \\
\hline K & $\begin{array}{c}1417.57 \pm \\
21.13 \mathrm{~d}\end{array}$ & $\begin{array}{c}1644.99 \pm \\
10.29 \mathrm{c}\end{array}$ & $\begin{array}{l}1674 \\
\pm 4.5\end{array}$ & $\begin{array}{c}1759.23 \pm \\
10.21 \mathrm{a}\end{array}$ \\
\hline $\mathrm{Mg}$ & & $\begin{array}{c}1043.35 \pm \\
8.95 \mathrm{a}\end{array}$ & $\begin{array}{c}967.16 \pm \\
5.01 \mathrm{~b}\end{array}$ & $\begin{array}{c}984.63 \pm 1 \\
1.76 \mathrm{~b}\end{array}$ \\
\hline $\mathrm{Mn}$ & $\begin{array}{c}19.45 \pm 0.3 \\
2 \mathrm{c}\end{array}$ & $\begin{array}{c}22.05 \pm 0.3 \\
1 \mathrm{~b}\end{array}$ & $\begin{array}{c}22.16 \pm 0 \\
01 \mathrm{~b}\end{array}$ & $\begin{array}{c}23.89 \pm 0.0 \\
4 \mathrm{a}\end{array}$ \\
\hline $\mathrm{Na}$ & $\begin{array}{c}181.23 \pm 0 \\
23 b\end{array}$ & $\begin{array}{c}179.91 \pm 1 \\
51 \mathrm{~b}\end{array}$ & $\begin{array}{c}186.86 \pm \\
0.82 \mathrm{a}\end{array}$ & $\begin{array}{c}167.19 \pm 2 . \\
63 \mathrm{c}\end{array}$ \\
\hline $\mathrm{Zn}$ & $\begin{array}{c}35.12 \pm 0.2 \\
3 \mathrm{~b}\end{array}$ & $\begin{array}{c}22.88 \pm 0.1 \\
1 \mathrm{c} \\
\end{array}$ & $\begin{array}{c}41.34 \pm 0 \\
31 \mathrm{a}\end{array}$ & $\begin{array}{c}20.35 \pm 0.0 \\
8 \mathrm{~d} \\
\end{array}$ \\
\hline Total & 2781.12 & 2995.95 & 2992.04 & 3012.23 \\
\hline
\end{tabular}

1) Samples are defined in Table 1. ${ }^{2}$ Values are expressed as mean \pm standard deviation of two replicates. Values followed by different letters ( $a, b$, $c$, and d) in the same row are significantly different $(\mathrm{p}<0.05$, ANOVA, Tukey test $)$.

Like the GABA content, the mineral content of the GBR samples was increased by 
soaking brown rice in the mineral-rich Pu-erh tea (McKenzie et al., 2010). Similar results of higher zinc content were found in the zinc sulfate-applied soybean sprouts (Xu et al., 2012; Zou et al., 2014). Minerals, including $\mathrm{Fe}$ and $\mathrm{Zn}$, which were increased in some of the Pu-erh tea extract-treated GBR samples, are some of the most commonly lacking elements in human diets (White and Broadley, 2009). Minerals $\mathrm{Mg}$ and $\mathrm{K}$ are beneficial against hypertension (Houston and Harper, 2008); Fe plays roles in oxygen transport, energy metabolism, mitochondrial respiration, DNA synthesis, and cellular growth and differentiation (Ganz, 2013); Zn contributes to the growth, development, differentiation, DNA synthesis, RNA transcription, and cellular apoptosis (MacDiarmid, 2000).

\subsection{DPPH inhibition activities and total polyphenol and flavonoid contents}

The antioxidant potentials of the GBR samples were determined through DPPH inhibition activities as well as total polyphenol and flavonoid contents (Table 4). The DPPH free radical scavenging potentials of GBR-1.5 (72.49\%) and GBR-3 (76.18\%) were significantly higher than that of GBR-0 $(62.56 \%)$ and GBR-0.5 (62.58\%). The total polyphenol content was highest in GBR-0.5 (164.19 $\mu \mathrm{g}$ GAE/g) followed by GBR-0 (152.58 $\mu \mathrm{g}$ GAE/g), GBR-1.5 (143.38 $\mu \mathrm{g}$ GAE/g), and GBR-3 (130.53 $\mu \mathrm{g} \mathrm{GAE} / \mathrm{g})$. The flavonoid contents of GBR-1.5 (36.17 $\mu \mathrm{g}$ $\mathrm{QE} / \mathrm{g}$ ) was the significantly lowest among the samples (39.69-41.48 $\mu \mathrm{g}$ QE/g).

Several reactive oxygen species (ROS), such as hydrogen peroxide, hydroxyl radical, and singlet oxygen cause oxidative damage in lipids, proteins, and DNA (Santos et al., 2003). Production of excessively high levels of the ROS may harm the cells by lipids peroxidation, proteins oxidation, nucleic acids destruction, enzyme inhibition, programmed cell death activation pathway, and eventually cells death (Mishra et al.,
2011; Srivastava and Dubey, 2011). The higher levels of biosynthesis of antioxidants in the tea extract-treated samples might be resulted from the high contents of elements like calcium (McKenzie et al., 2010) and/or phenolic compounds (Zhang et al., 2012; Chen et al., 2017) in Pu-erh tea.

Table 4. DPPH inhibition activities and total polyphenol and flavonoid contents of germinated brown rice (GBR) produced after soaking in different concentration of $\mathrm{Pu}$-erh tea extracts

\begin{tabular}{|l|c|c|c|}
\hline $\begin{array}{l}\text { Sampl } \\
\mathbf{e}^{\mathbf{1})}\end{array}$ & $\begin{array}{c}\text { DPPH (\% } \\
\text { inhibition) }\end{array}$ & $\begin{array}{c}\text { Total } \\
\text { polyphenol } \\
\left(\boldsymbol{\mu g} \mathbf{G A E} \mathbf{~}^{2} / \mathbf{g}\right)\end{array}$ & $\begin{array}{c}\text { Flavonoid } \\
(\boldsymbol{\mu g} \mathbf{Q E} \\
\mathbf{3} / \mathbf{g})\end{array}$ \\
\hline GBR-0 & $\begin{array}{c}62.56 \pm 1.22 \mathrm{c}^{4} \\
)\end{array}$ & $\begin{array}{c}152.58 \pm 3.26 \mathrm{~b} \\
4)\end{array}$ & $\begin{array}{c}39.69 \pm 1.88 \\
\mathrm{a}\end{array}$ \\
\hline $\begin{array}{l}\text { GBR- } \\
0.5\end{array}$ & $62.58 \pm 2.05 \mathrm{c}$ & $164.19 \pm 0.72 \mathrm{a}$ & $\begin{array}{c}41.35 \pm 0.68 \\
\mathrm{a}\end{array}$ \\
\hline $\begin{array}{l}\text { GBR- } \\
1.5\end{array}$ & $72.49 \pm 1.64 \mathrm{~b}$ & $143.38 \pm 2.68 \mathrm{c}$ & $\begin{array}{c}36.17 \pm 1.59 \\
\mathrm{~b}\end{array}$ \\
\hline GBR-3 & $76.18 \pm 2.12 \mathrm{a}$ & $130.53 \pm 0.77 \mathrm{~d}$ & $\begin{array}{c}41.48 \pm 2.60 \\
\mathrm{a}\end{array}$ \\
\hline
\end{tabular}

${ }^{1)}$ Samples are defined in Table $1 .{ }^{2)}$ GAE: gallic acid equivalents. ${ }^{3)} \mathrm{QE}$ : quercetin equivalents. ${ }^{4)}$ Values are expressed as mean \pm standard deviation of three replicates. Values followed by different letters $(a, b$, $c$, and d) in the same column are significantly different $(\mathrm{p}<0.05$, ANOVA, Tukey test).

The results of this study are in agreement with that of previous reports of high phenolic contents in the germinated brown rice when the rice was treated with high phenoliccontaining onions (Gennaro et al., 2002; Griffiths et al., 2002; Nakamura et al., 2020). Phenolic compounds have antioxidant potentials (Rice-evans et al., 1995; Yang et al., 2015) that can scavenge harmful free radicals. In addition to phenolic compounds, various enzymatic and non-enzymatic antioxidants, such as superoxide dismutase, catalase, glutathione peroxidase, glutathione transferase, vitamin $\mathrm{C}$, vitamin $\mathrm{E}$, polyphenols, and carotenoids possess the free radical scavenging potentials. The antioxidant potential of foods is a multifaceted outcome of several factors, such as the partitioning properties of specific 
antioxidants, oxidation conditions, and the physical state of the oxidizable substrate (Frankel and Meyer, 2000). Thus, a visible difference in the level of an individual antioxidant such as total polyphenol and/or flavonoid might not always account for higher antioxidant activity, as in the GBR samples with higher DPPH radical scavenging potential but lower total polyphenol and/or flavonoid.

\section{Conclusions}

The influence of Pu-erh tea extracts on GBR was investigated considering the physicochemical characteristics and antioxidant potentials. The color values of GBR were significantly modified with the tea extract treatments. Although the total free amino acids of the extract-treated GBR samples were lower than the untreated one, the amount of some amino acids like GABA were increased. In addition, the amount of total minerals and antioxidant potentials of the extract-treated GBR samples were higher than that of the untreated one. Overall, the nutritional and functional properties of brown rice could be enhanced by soaking it in $\mathrm{Pu}$ erh tea extracts $(0.5-3 \%, \mathrm{w} / \mathrm{v})$.

\section{References}

Blois, M. S. (1958). Antioxidant determinations by the use of a stable free radical. Nature, 181, 1199-1200.

Chaikina, E. L., Gerasimenko, N. I., Dega, L. A., Vashchenko, A. P., Anisimov, M. M. (2009). Effect of ethanol metabolites of seersucker kelp Costaria costata on growth of soybean sprouts. Russian Agricultural Sciences, 35(5), 307-309.

Chen, M., Zhu, Y., Zhang, H., Wang, J., Liu, X., Chen, Z., Zheng, M., Liu, B. (2017). Phenolic compounds and the biological effects of Pu-erh teas with long-term storage. International Journal of Food Properties, 20(8), 1715-1728.

Dhakal, R., Bajpai, V. K., Baek, K.-H. (2012). Production of gaba $(\gamma-$ aminobutyric acid) by microorganisms: a review. Brazilian Journal of Microbiology, 43(4), 1230-1241.

Dhungana, S. K., Kim, B.-R., Son, J.-H., Kim, H.-R., Shin, D.-H. (2015). Comparative Study of CaMsrB2 Gene Containing Drought-Tolerant Transgenic Rice (Oryza sativa L.) and NonTransgenic Counterpart. Journal of Agronomy and Crop Science, 201(1), 1016.

Dhungana, S. K., Kim, I.-D., Kwak, H.-S., Shin, D.-H. (2016). Unraveling the effect of structurally different classes of insecticide on germination and early plant growth of soybean [Glycine max (L.) Merr.]. Pesticide Biochemistry and Physiology, 130, 39-43.

Dinesh Babu, P., Subhasree, R. S., Bhakyaraj, R., Vidhyalakshmi, R. (2009). Brown rice-beyond the color reviving a lost health food - A review. AmericanEurasian Journal of Agronomy, 2(2), 6772.

Eslami, S., Esa, N. M., Marandi, S. M., Ghasemi, G., Eslami, S. (2014). Effects of gamma oryzanol supplementation on anthropometric measurements \& muscular strength in healthy males following chronic resistance training. Indian Journal of Medical Research, 139(6), 857-863.

Frankel, E. N., Meyer, A. S. (2000). The problems of using one-dimensional methods to evaluate multifunctional food and biological antioxidants. Journal of the Science of Food and Agriculture, 80(13), 1925-1941.

Ganz, T. (2013). Systemic iron homeostasis. Physiological Reviews, 93(4), 1721-1741. Gennaro, L., Leonardi, C., Esposito, F., Salucci, M., Maiani, G., Quaglia, G., Fogliano, V. (2002). Flavonoid and carbohydrate contents in tropea red onions: Effects of homelike peeling and storage. Journal of Agricultural and Food 
Chemistry, 50(7), 1904-1910.

Griffiths, G., Trueman, L., Crowther, T., Thomas, B., Smith, B. (2002). Onions A global benefit to health. Phytotherapy Research, 16(7), 603-615.

Houston, M. C., Harper, K. J. (2008). Potassium, magnesium, and calcium: Their role in both the cause and treatment of hypertension. The Journal of Clinical Hypertension, 10(7), 3-11.

Imam, M. U., Ishaka, A., Ooi, D.-J., Zamri, N. D. M., Sarega, N., Ismail, M., Esa, N. M. (2014). Germinated brown rice regulates hepatic cholesterol metabolism and cardiovascular disease risk in hypercholesterolaemic rats. Journal of Functional Foods, 8, 193-203.

Ito, Y., Shen, M., Kise, M., Hayamizu, K., Yoshino, G., Yoshihara, R., Yokoyama, J. (2005). Effect of pre-germinated brown rice on postprandial blood glucose and insulin level in subjects with hyperglycemia. Japanese Journal of Food Chemistry and Safety, 12(2), 80-84.

Je, J.-Y., Park, P.-J., Jung, W.-K., Kim, S.-K. (2005). Amino acid changes in fermented oyster (Crassostrea gigas) sauce with different fermentation periods. Food Chemistry, 91(1), 15-18.

Kim, I.-D., Dhungana, S. K., Park, Y.-S., Kim, D., Shin, D.-H. (2017). Persimmon fruit powder may substitute Indolbi, a synthetic growth regulator, in soybean sprout cultivation. Molecules, 22(9), 1462.

Kim, I.-D., Lee, J.-W., Kim, S.-J., Cho, J.W., Dhungana, S. K., Lim, Y.-S., Shin, D.H. (2014). Exogenous application of natural extracts of persimmon (Diospyros kaki Thunb.) can help in maintaining nutritional and mineral composition of dried persimmon. African Journal of Biotechnology, 13(22), 2231-2239.

Komatsuzaki, N., Tsukahara, K., Toyoshima, H., Suzuki, T., Shimizu, N., Kimura, T. (2007). Effect of soaking and gaseous treatment on GABA content in germinated brown rice. Journal of Food Engineering, 78(2), 556-560.

Lee, L. K., Foo, K. Y. (2013). Recent advances on the beneficial use and health implications of Pu-Erh tea. Food Research International, 53(2), 619-628.

Li, S.-C., Lin, H.-P., Chang, J.-S., Shih, C.K. (2019). Lactobacillus acidophilusFermented Germinated Brown Rice Suppresses Preneoplastic Lesions of the Colon in Rats. Nutrients, 11(11), 2718.

MacDiarmid, C. W. (2000). Zinc transporters that regulate vacuolar zinc storage in Saccharomyces cerevisiae. The EMBO Journal, 19(12), 2845-2855.

McKenzie, J. S., Jurado, J. M., de Pablos, F. (2010). Characterisation of tea leaves according to their total mineral content by means of probabilistic neural networks. Food Chemistry, 123(3), 859-864.

Mishra, S., Jha, A. B., Dubey, R. S. (2011). Arsenite treatment induces oxidative stress, upregulates antioxidant system, and causes phytochelatin synthesis in rice seedlings. Protoplasma, 248(3), 565-577.

Mody, I., De Koninck, Y., Otis, T. S., Soltesz, I. (1994). Bridging the cleft at GABA synapses in the brain. Trends in Neurosciences, 17(12), 517-525.

Nakamura, S., Kaneko, K., Mitsui, T., Ohtsubo, K. (2020). Evaluation of the palatability and biofunctionality of brown rice germinated in red onion solution. Cereal Chemistry, 97(4), 836-848.

Nakamura, S., Nakano, Y., Satoh, H., Ohtsubo, K. (2013). Improved palatability and bio-functionality of super-hard rice by soaking in a barley- Koji Miso suspension. Bioscience, Biotechnology, and Biochemistry, 77(12), 2419-2429.

Oh, C.-H., Oh, S.-H. (2004). Effects of ferminated brown rice extracts with enhanced levels of GABA on cancer cell proliferation and apoptosis. Journal of Medicinal Food, 7(1), 19-23.

Okada, T., Sugishita, T., Murakami, T., 
Murai, H., Saikusa, T., Horino, T., Onoda, A., Kajimoto, O., Takahashi, R., Takahashi, T. (2000). Effect of the defatted rice germ enriched with GABA for sleeplessness, depression, autonomic disorder by oral administration. Nippon Shokuhin Kagaku Kogaku Kaishi, 47(8), 596-603.

https://doi.org/10.3136/nskkk.47.596

Patil, S. B., Khan, M. K. (2011). Germinated brown rice as a value added rice product: A review. Journal of Food Science and Technology, 48(6), 661-667.

Petchdee, S., Laosripaiboon, W., Jarussophon, N., Kumphune, S. (2020). Cardio-protective effects of germinated brown rice extract against myocardial ischemia reperfusion injury. High Blood Pressure \& Cardiovascular Prevention, 27(3), 251-258.

Reeds, P. J. (2000). Dispensable and indispensable amino acids for humans. The Journal of Nutrition, 130(7), 1835S$1840 \mathrm{~S}$.

Rice-evans, C. A., Miller, N. J., Bolwell, P. G., Bramley, P. M., Pridham, J. B. (1995). The relative antioxidant activities of plantderived polyphenolic flavonoids. Free Radical Research, 22(4), 375-383.

Santos, J. H., Hunakova, L., Chen, Y., Bortner, C., Van Houten, B. (2003). Cell sorting experiments link persistent mitochondrial DNA damage with loss of mitochondrial membrane potential and apoptotic cell death. Journal of Biological Chemistry, 278(3), 1728-1734.

Singleton, V. L., Orthofer, R., LamuelaRaventós, R. M. (1999). Analysis of total phenols and other oxidation substrates and antioxidants by means of folin-ciocalteu reagent. Methods in Enzymology, 299. 152-178).

Skujins, S. (1998). Handbook for ICP-AES (Varian-Vista). A Short Guide to Vista Series ICP-AES Operation. Varian Int. AG, Zug, Version 1.0, Switzerland.
Spanier, A. M., Shahidi, F., Parliment, T. H., Mussinan, C., Ho, C.-T., Tratras Contis, E., Kayahara, H., Tsukahara, K., \& Tatai, T. (2001). Flavor, health and nutritional quality of pre-germinated brown rice. In A. M. Spanier, F. Shahidi, T. H. Parliment, C. Mussinan, C.-H. Ho, C. T. Contis (Eds.), Food flavors and chemistry: Advances of the new millennium (pp. 546-551). Royal Society of Chemistry.

Srivastava, S., Dubey, R. S. (2011). Manganese-excess induces oxidative stress, lowers the pool of antioxidants and elevates activities of key antioxidative enzymes in rice seedlings. Plant Growth Regulation, 64(1), 1-16.

Udomkun, P., Ilukor, J., Mockshell, J., Mujawamariya, G., Okafor, C., Bullock, R., Nabahungu, N. L., Vanlauwe, B. (2018). What are the key factors influencing consumers' preference and willingness to pay for meat products in Eastern DRC? Food Science \& Nutrition, 6(8), 2321-2336.

Wang, X., Yang, R., Jin, X., Shen, C., Zhou, Y., Chen, Z., Gu, Z. (2016). Effect of supplemental $\mathrm{Ca} 2+$ on yield and quality characteristics of soybean sprouts. Scientia Horticulturae, 198, 352-362.

White, P. J., Broadley, M. R. (2009). Biofortification of crops with seven mineral elements often lacking in human diets - iron, zinc, copper, calcium, magnesium, selenium and iodine. New Phytologist, 182(1), 49-84.

$\mathrm{Xu}$, N., Zou, T., Pang, J. W., Hu, G. L. (2012). Effects of exogenous zinc soaking on the seed germination, sprout growth of soybean and zinc accumulation in the sprouts. Soybean Science, 31(6), 932-936.

Yang, R., Guo, L., Zhou, Y., Shen, C., Gu, Z. (2015). Calcium mitigates the stress caused by $\mathrm{ZnSO}_{4}$ as a sulphur fertilizer and enhances the sulforaphane formation of broccoli sprouts. RSC Advances, 5(17), 12563-12570. 
Yang, R., Jiang, Y., Xiu, L., Huang, J. (2019). Effect of chitosan pre-soaking on the growth and quality of yellow soybean sprouts. Journal of the Science of Food and Agriculture, 99(4), 1596-1603.

Yodpitak, S., Mahatheeranont, S., Boonyawan, D., Sookwong, P., Roytrakul, S., Norkaew, O. (2019). Cold plasma treatment to improve germination and enhance the bioactive phytochemical content of germinated brown rice. Food Chemistry, 289, 328-339.

Zhang, H.-M., Wang, C.-F., Shen, S.-M., Wang, G.-L., Liu, P., Liu, Z.-M., Wang, Y.-Y., Du, S.-S., Liu, Z.-L., Deng, Z.-W. (2012). Antioxidant phenolic compounds from Pu-erh tea. Molecules, 17(12), 14037-14045.

Zhang, Q., Liu, N., Wang, S., Liu, Y., Lan, H. (2019). Effects of cyclic cellulase conditioning and germination treatment on the $\gamma$-aminobutyric acid content and the cooking and taste qualities of germinated brown rice. Food Chemistry, 289, 232239.

Zhishen, J., Mengcheng, T., Jianming, W. (1999). The determination of flavonoid contents in mulberry and their scavenging effects on superoxide radicals. Food Chemistry, 64(4), 555-559.

Zhong, L., Wang, X., Yang, R., Guo, L., Gu, Z. (2014). Influence of $\mathrm{NaHCO}_{3}$ soaking on phytic acid content of soybean sprouts and the optimization of its germination conditions. Journal of Nanjing Agricultural University, 37(3), 167-172 (2014).

Zhu, H. T., Yang, C. R., Li, Y., Zhang, Y. J. (2008). Advances on the research of microbes during the post-fermentative process of Pu-erh tea. Acta Botanica Yunnanica, 30, 718-724.

Zou, T., Xu, N., Hu, G., Pang, J., Xu, H. (2014). Biofortification of soybean sprouts with zinc and bioaccessibility of zinc in the sprouts. Journal of the Science of Food and Agriculture, 94(14), 30533060 . 